\title{
Anti-inflammatory and antioxidant activities of Moringa peregrina Seeds
}

\author{
${ }^{1}$ Mahmoud A. Koheil, ${ }^{2}$ Mohammed A. Hussein*, ${ }^{3}$ Samir M. Othman and ${ }^{3}$ Alaa El-Haddad \\ ${ }^{1}$ Department of Pharmacognosy, Faculty of Pharmacy, Cairo University, Cairo, Egypt. \\ ${ }^{2 *}$ Department of Biochemistry, Faculty of Pharmacy, October $6^{\text {th }}$ University, October $6^{\text {th }}$ City, Egypt. \\ ${ }^{3}$ Department of Pharmacognosy, Faculty of Pharmacy, October $6^{\text {th }}$ University, October $6^{\text {th }}$ City, Egypt.
}

\begin{abstract}
The present study was carried out to evaluate the anti-inflammatory and antioxidant activities of Moringa peregrina seeds ethanolic and aqueous extracts. The anti-inflammatory effect Moringa peregrina extracts was examined in rats, using fresh egg albumin-induced oedema, and diclofenac $(100 \mathrm{mg} / \mathrm{kg})$ was used as reference drug for comparison. The methods selected to design a convenient system to assess the antioxidant activity of Moringa peregrina extracts including, reducing power, chelating activity on $\mathrm{Fe}^{2+}$, free radical-scavenging, total antioxidant, superoxide radical scavenging, hydrogen peroxide scavenging and hydroxyl radical scavenging activities in an attempt to understand its mechanism of action, which may pave the way for possible therapeutic applications. In addition, the results were compared with natural and synthetic antioxidants, such as $\alpha$-tocopherol, ascorbic acid, butylated hydroxytoluene(BHT), butylated hydroxyanisole (BHA) and trolox. The results indicated that Moringa peregrina ethanolic and aqueous extracts $(100-300 \mathrm{mg} / \mathrm{kg}$ p. o.) also dose-dependently and significantly inhibited $(p<0.05-0.001)$ fresh egg albumin-induced acute inflammation. Ethanolic and aqueous extracts of Moringa peregrina exhibited a strong reducing power, $\mathrm{Fe}^{2+}$ chelating effect, free radical scavenging activity, hydrogen peroxide scavenging ability, and hydroxyl radical scavenging activity. Antioxidant activity of the ethanolic and aqueous extracts increased with increased concentrations in the range of $20-140 \mu \mathrm{g} / \mathrm{ml}$ the extracts also exhibited a strong superoxide radical scavenging activity. This study showed that Moringa peregrina extracts exhibited antioxidant activity in all tests and the extracts could be considered as a source of natural antioxidants. Taken together, Moringa peregrina has potential as an anti-inflammatory and antioxidant agent against inflammation and free radicals and deserves clinical trial in the near future.
\end{abstract}

Key words: Moringa peregrina, anti-inflammatory, antioxidant activity, $\alpha$-tocopherol, ascorbic acid and butylated hydroxytoluene (BHT), butylated hydroxyanisole (BHA).

*Corresponding author: Tel.: +2 (012) 4832580; fax: +2 (02) 38353270.;

E-mail: abdallamohammed_304@yahoo.com

DOI: $10.5530 /$ ax.2011.2.10

\section{INTRODUCTION}

The exogenous chemicals and endogenous metabolites in the body produce reactive oxygen species (ROS), which are capable of oxidizing various biomolecules resulting in tissue damage and cell death. Free radicals have been implicated in the cause of several diseases such as liver cirrhosis, atherosclerosis, cancer and diabetes and play an important role in ageing. Oxidative stress can also contribute to the development of neuro-degenerative disorders, such as Alzheimer's and Parkinson's as well as other diseases. These free radicals attack unsaturated fatty acids of biomembranes, resulting in lipid peroxidation and desaturation of proteins and DNA, causing a series of deteriorative changes in the biological systems leading to cell inactivation. ${ }^{[1]}$ Many antioxidant enzymes and compounds present in the cell, mitigate the oxidative stress due to free radicals, by dismutating these free radicals species or by converting these radicals into a less effective forms ${ }^{[2]}$ Antioxidant supplements or antioxidant-rich food are used to help the human body reduce oxidative damage from free radicals and active oxygen species. ${ }^{[3]}$ Other synthetic antioxidants such as butylated hydroxytoluene (BHT), butylated hydroxyanisole (BHA) and trolox are widely used as antioxidants in the pharmaceutical and food industry. However, they have been shown to have toxic and/or mutagenic effects. ${ }^{[2]}$ Because of their toxicity, the development and isolation of natural antioxidants 
from plant species, such as polyphenols are in progress. ${ }^{[4]}$ Many plant extracts are important constituents of human diet and have been suggested to have beneficial function in human health. ${ }^{[5-8]}$ Phenolic compounds constitute one of the largest groups of phytochemicals which present in foods such as flavonoids and other phenolic compounds have been identified to be potent antioxidants as well as anticarcinogenic agents. ${ }^{[9,10]}$ Polyphenols exist in many plants and are especially abundant in the Moringa tree, ${ }^{[1]}$ whose dried leaves are used as antioxidant. Moringa and polyphenol-enriched plant extracts have no known toxicity and represent a promising antioxidant activity. ${ }^{[12]}$ Moringa oleifera belongs to the Moringae family, commonly known as a drumstick tree that is native to tropical Africa and India and widely naturalised and cultivated in many countries including Malaysia. ${ }^{[13]} \mathrm{A}$ literature survey indicated that the presence of quercetin flavonoids, ${ }^{[14]}$ sterols, ${ }^{[15]}$ tocopherols $(\gamma$ and $\alpha), \beta$-carotene and vitamin C. In addition, Plant family is rich in essential sulfur amino acids; methionine and cysteine, ${ }^{[16]}$ essential oils, ${ }^{[17]}$ antioxidants, ${ }^{[18]}$ glucosinolates and isothiocyanates. ${ }^{[19]}$

Besides being a source of nutrients, ${ }^{[20]}$ studies have also demonstrated beneficial properties of this tree such as anticoagulant activity for water and waste water treatment, ${ }^{[2]}$ anti-inflammatory and antinociceptive activities $^{[22]}$ as well as wound healing property. ${ }^{[23]}$ In ayurvedic practice of India, Moringa has been used for treatment of various liver disorders. ${ }^{[24]}$ We have recently reported that Moringa oleifera may have protected the liver in hepatotoxicity via increasing the level of glutathione. ${ }^{[25,26]}$ As an extension of our interested research program in the extraction and therapeutic evaluation of rare medicinal plants, ${ }^{[5-8]}$ we report herein, a facile route to explain the anti-inflammatory and antioxidant effects of Moringa peregrina extracts which may pave the way for possible therapeutic application.

\section{MATERIALS AND METHODS}

\section{Chemicals}

$\alpha$ - tocopherol, ascorbic acid, butylated hydroxytoluene (BHT), butylated hydroxyanisole (BHA) and trolox were from Sigma, USA. All other chemicals used were analytical grade and obtained from either Sigma-Aldrich or Merck.

\section{Plant material}

The seeds of $M$. Peregrina were purchased from the herbalist. The taxonomical features of the plant were kindly confirmed by Dr. A. A. Abd El Meged, Prof. of Plant Taxonomy, Agriculture research center, Cairo, Egypt. Voucher specimens were kept in the department of Pharmacognosy, Faculty of Pharmacy, October 6 University.

\section{Preparations of the extracts}

Preparation of ethanolic extract: $M$. peregrina seeds (500 g) were crushed to coarse powder and extracted exhaustively in a Soxhlet with $70 \%$ ethanol. The extract was concentrated under reduced pressure to yield viscous mass. The ethanolic extract was kept in airtight containers in a deep freeze maintained at $4{ }^{\circ} \mathrm{C}$ until the time of further use.

Preparation of aqueous extract: The aqueous extract of $M$. peregrine seeds was prepared by dissolving a known amount of $M$. peregrine seeds powder in (warm distilled water $60-70{ }^{\circ} \mathrm{C}$ ) using a magnetic stirrer. It was then filtered and evaporated to dryness under reduced pressure. An aqueous suspension, which is the form customarily, used in folk medicine, was prepared to facilitate easy handling.

Phytochemical Screening: A phytochemical analysis of seeds of $M$. peregrine was conducted for the detection of alkaloids, cardiac glycosides, flavonoids, tannins, anthraquinones, saponins, volatile oil, coumarins and cyanophoric glycosides. ${ }^{[27]}$

\section{METHODS}

\section{Evaluation of Anti-inflammatory Property}

The rats used were divided into three broad (A, B, C and D) experimental groups of 8 rats per group. Group $A$ rats were used as controls, and each animal in this group (A) received distilled water ( $3 \mathrm{ml} / \mathrm{kg}$ i.p.) only. Group B 'test' rats received Moringa peregrine ethanolic extract (100-300 mg/kg i.p.). Group C 'test' rats received Moringa peregrina aqueous extract (100-300 mg/kg i.p.). Group D 'test' rats received diclofenac (100 mg/kg i. p.). The rat hind paw oedema was used as a model of acute inflammation. Rat hind paw oedema was induced by intra-plantar injection of fresh egg albumin $(0.5 \mathrm{ml} / \mathrm{kg}){ }^{[28]}$ Acute inflammation of the right hind paw was induced in each of the rats by injecting $0.5 \mathrm{ml} / \mathrm{kg}$ of fresh egg albumin into the surface of the right hind paw. Pedal inflammation (oedema) was always evident within 5-8 min 
following fresh egg albumin $(0.5 \mathrm{ml} / \mathrm{kg})$ injection. Linear diameter of the injected paw was measured (with a transparent millimeter ruler) for $3 \mathrm{~h}$ at 30 -minute intervals after the administration of the fresh egg albumin. Increases in the linear diameter of the right hind paws were taken as indicators of paw oedema. Oedema was assessed in terms of the difference in the 'zero time' $\left(\mathrm{C}_{\mathrm{o}}\right)$ linear diameter of the injected right hind paw, and its linear diameter at 'time t' $\left[\left(\mathrm{C}_{\mathrm{t}}\right)\right.$-that is, 30, 60, 90, 120 and $180 \mathrm{~min}$ ] following fresh egg albumin administration. The increases in the right hind paw diameters induced by injections of fresh egg albumin were compared with those of the contra-lateral, non-injected left hind paw diameters. ${ }^{[2]}$ Moringa peregrina ethanolic and aqueous extracts were separately administered at doses of 100$300 \mathrm{mg} / \mathrm{kg}$ (i.p.) to each of the rats in the 'test' Groups $\mathrm{B}$ and/or C, $20 \mathrm{~min}$ before inducing inflammation with the injection of fresh egg albumin. Rats in the reference, comparative 'test' Group D received diclofenac $(100 \mathrm{mg} / \mathrm{kg}$ i. p.); while rats in the 'control' Group A received distilled water $(3 \mathrm{ml} / \mathrm{kg}$ i. p.) only.

Percentage inflammation (oedema) was calculated from the formula:

$$
\frac{\mathrm{C}_{\mathrm{o}}}{\mathrm{C}_{\mathrm{t}}} \times 100
$$

Percentage inhibition of the oedema was calculated from the formula:

$$
\frac{C_{o}-C_{t}}{C_{o}} \times 100
$$

[where $\mathrm{C}_{\mathrm{o}}$ is the average inflammation (hind paw oedema) of the 'control' Group A rats at a given time; and $C_{t}$ is the average inflammation of the (Groups B and/or C) plant's extracts or (Group D) diclofenac-treated rats at the same time].

\section{Evaluation of Antioxidant Property}

1. Determination of reducing power: The reducing power of ethanolic and aqueous extracts of Moringa peregrina was measured according to the method of Oyaizu. ${ }^{[30]}$ Various concentrations of extracts $(20-140 \mu \mathrm{g})$ in $1 \mathrm{ml}$ of distilled water were mixed with $2.5 \mathrm{ml}$ of phosphate buffer $(0.2 \mathrm{M}, \mathrm{pH} 7.6)$ and $2.5 \mathrm{ml}$ potassium ferricyanide $\left[\mathrm{K}_{3} \mathrm{Fe}(\mathrm{CN})_{6}\right](1 \%, \mathrm{w} / \mathrm{v})$, and then the mixture was incubated at $50{ }^{\circ} \mathrm{C}$ for $30 \mathrm{~min}$. Afterwards, $2.5 \mathrm{ml}$ of trichloroacetic acid $(10 \%, \mathrm{w} / \mathrm{v})$ was added to the mixture, which was then centrifuged at $3000 \mathrm{rpm}$ for $10 \mathrm{~min}$. Finally, $2.5 \mathrm{ml}$ of upper-layer solution was mixed with $2.5 \mathrm{ml}$ distilled water and $0.5 \mathrm{ml} \mathrm{FeCl}_{3}$
$(0.1 \%, \mathrm{w} / \mathrm{v})$, and the absorbance was measured at $700 \mathrm{~nm} . \alpha$ - tocopherol, BHA and BHT were used as standard antioxidants. Higher absorbance of the reaction mixture indicated greater reducing power.

2. Determination of chelating activity on $\mathbf{F e}^{2+}$ : The chelating activity of ethanolic and aqueous extracts of Moringa peregrina on ferrous ions $\left(\mathrm{Fe}^{2+}\right)$ was measured according to the method of Decker and Welch. ${ }^{[31]}$ Aliquots of $1 \mathrm{ml}$ of different concentrations $(0.25,0.50$, 0.75 and $1.0 \mathrm{mg} / \mathrm{ml}$ ) of the extracts were mixed with $3.7 \mathrm{ml}$ of deionized water. The mixture was incubated with $\mathrm{FeCl}_{2}(2 \mathrm{mM}, 0.1 \mathrm{ml})$ for 5, 10, 30 and $60 \mathrm{~min}$. After incubation the reaction was initiated by addition of ferrozine $(5 \mathrm{mM}$ and $0.2 \mathrm{ml}$ ) for $10 \mathrm{~min}$ at room temperature, and then the absorbance was measured at $562 \mathrm{~nm}$ in a spectrophotometer. A lower absorbance indicates a higher chelating power. The chelating activity of extracts on $\mathrm{Fe}^{2+}$ was compared with that of EDTA at a level of $0.037 \mathrm{mg} / \mathrm{ml}$. Chelating activity was calculated using the following formula:

Chelating activity $(\%)=$

$$
\left[1-\left(\frac{\text { Absorbance of sample }}{\text { Absorbance of control }}\right) \times 100\right]
$$

Control test was performed without addition of extracts.

\section{Determination of free radical-scavenging} activity: The free radical scavenging activity of ethanolic and aqueous extracts of Moringa peregrina was measured with 1,1-diphenyl-2-picrylhydrazil (DPPH) using the slightly modified methods of Brand William et al. ${ }^{[32]}$ and Takashira and Ohtake. ${ }^{[33]}$ Briefly, $6 \times 10^{-5} \mathrm{~mol} / 1 \mathrm{DPPH}^{*}$ solution in ethanol was prepared and $3.9 \mathrm{ml}$ of this solution was added to $0.1 \mathrm{ml}$ of the extracts $(2-6 \mathrm{mg} / \mathrm{ml})$ and trolox solution $(0.02-0.06 \mathrm{mg} / \mathrm{ml})$. The mixture was shaken vigorously and the decrease in absorbance at $517 \mathrm{~nm}$ was measured at 5, 10, 30 and $60 \mathrm{~min}$. Water $(0.1 \mathrm{ml})$ in place of extracts was used as control. The percent inhibition activity was calculated using the following equation:

$$
\text { Inhibition activity }(\%)=\left[\frac{\left(A_{0}-A_{1}\right)}{A_{0} \times 100}\right],
$$

Where $\mathrm{A}_{0}$ is the absorbance of the control reaction and $A_{1}$ is the absorbance in the presence of extracts.

\section{Determination of total antioxidant activity} determination: The antioxidant activity was determined according to the thiocyanate method with slight modifications. ${ }^{[34]}$ For the stock solution, $10 \mathrm{mg}$ of 
ethanolic and aqueous extracts of Moringa peregrina was dissolved in $10 \mathrm{ml}$ water. Then the solution of extracts or standards samples (tocopherol, trolox, BHA and BHT) $[100 \mathrm{mg} / \mathrm{l}]$ in $2.5 \mathrm{ml}$ of potassium phosphate buffer (0.04 M, pH 7.6) was added to $2.5 \mathrm{ml}$ of linoleic acid emulsion. Fifty $\mathrm{ml}$ linoleic acid emulsion contained Tween-20 (175 $\mu \mathrm{g})$, linoleic acid (155 $\mu \mathrm{l})$ and potassium phosphate buffer (0.04 M, pH 7.6). On the other hand, $5.0 \mathrm{ml}$ of control contained $2.5 \mathrm{ml}$ of linoleic acid emulsion and $2.5 \mathrm{ml}$ of potassium phosphate buffer (0.04 M, pH 7.6). Each solution was then incubated at $37^{\circ} \mathrm{C}$ in a glass flask in the dark. At $24 \mathrm{~h}$ intervals during incubation, $0.1 \mathrm{ml}$ of this incubation solution was added to $4.7 \mathrm{ml}$ of $75 \%(\mathrm{v} / \mathrm{v})$ ethanol and $0.1 \mathrm{ml}$ of $30 \%$ $(\mathrm{w} / \mathrm{v})$ ammonium thiocyanate. Precisely $3 \mathrm{~min}$ after $0.1 \mathrm{ml}$ of $0.02 \mathrm{M} \mathrm{FeCl}_{2}$ in $3.5 \%$ (w/v) $\mathrm{HCl}$ was added to the reaction mixture, the absorbance of the red colour was measured at $500 \mathrm{~nm}$ in a spectrophotometer. The solutions without added extracts or standards were used as the control. The inhibition of lipid peroxidation in percentage was calculated by the following equation:

$$
\text { Inhibition } \%=\left[\frac{\left(A_{0}-A_{1}\right)}{A_{0} \times 100}\right] \text {, }
$$

Where $A_{0}$ is the absorbance of the control reaction and $\mathrm{A}_{1}$ is the absorbance in the presence of extracts or standards.

\section{Determination of superoxide radical scavenging} activity: Measurement of superoxide anion scavenging activity of ethanolic and aqueous extracts of Moringa peregrina was based on the method described by Liu et al. ${ }^{[35]}$ Superoxide anions were generated in a nonenzymatic phenazine methosulfate-nicotinamide adenine dinucleotide (PMS-NADH) system by oxidation of $\mathrm{NADH}$ and assayed by reduction of nitroblue tetrazolium (NBT). In this experiment, the superoxide anion was generated in $3 \mathrm{ml}$ of Tris- $\mathrm{HCl}$ buffer $(16 \mathrm{mM}, \mathrm{pH} 8.0)$ containing $1 \mathrm{ml}$ of NBT ( $50 \mu \mathrm{M})$ solution, $1 \mathrm{ml}$ of NADH $(78 \mu \mathrm{M})$ solution and different concentrations (0.1$1.25 \mathrm{mg} / \mathrm{ml}$ ) of sample solution. The reaction was started by adding $1 \mathrm{ml}$ of PMS-NADH solution $(10 \mu \mathrm{M})$ to the mixture. The reaction mixture was incubated at $25{ }^{\circ} \mathrm{C}$ for $5 \mathrm{~min}$ and absorbance at $560 \mathrm{~nm}$ was recorded against blank samples in a spectrophotometer. Trolox, ascorbic acid and BHA were used as standard samples (0.1$1.25 \mathrm{mg} / \mathrm{ml})$.

\section{Determination of hydrogen peroxide scavenging} activity: Ethanolic and aqueous extracts of Moringa peregrina $(100 \mu \mathrm{g} / \mathrm{ml})$ was dissolved in $3.4 \mathrm{ml}$ of $0.1 \mathrm{M}$ phosphate buffer ( $\mathrm{pH} 7.6$ ) and mixed with $0.6 \mathrm{ml}$ of $43 \mathrm{mM}$ hydrogen peroxide solution. The absorbance value (at $230 \mathrm{~nm}$ ) of the reaction mixture was recorded after $40 \mathrm{~min}$. For each concentration, a separate blank sample was used for background subtraction. ${ }^{[36]}$ $\alpha$ - tocopherol, BHT and BHA $(100 \mu \mathrm{g} / \mathrm{ml})$ were used as standard antioxidants. The solutions without added extracts or standards were used as the control. The percentage of scavenged hydrogen peroxide of extracts and standard compounds was calculated using the following equation:

$$
\text { Scavenged } \mathrm{H}_{2} \mathrm{O}_{2} \%=\left[\frac{\left(\mathrm{A}_{0}-\mathrm{A}_{1}\right)}{\mathrm{A}_{0} \times 100}\right],
$$

Where $A_{0}$ is the absorbance of the control and $A_{1}$ is the absorbance in the presence of extracts and standards.

\section{Determination of hydroxyl radical scavenging} activity: The effect of hydroxyl radical was assayed by using the 2-deoxyribose oxidation method. ${ }^{[37]}$ 2-Deoxyribose is oxidized by the hydroxyl radical that is formed by the Fenton reaction and degraded to malondialdehyde. The reaction mixture contained $0.45 \mathrm{ml}$ of $0.2 \mathrm{M}$ sodium phosphate ( $\mathrm{pH} 7.6$ ), $0.15 \mathrm{ml}$ of $10 \mathrm{mM}$ 2-deoxyribose, $0.15 \mathrm{ml}$ of $10 \mathrm{mM} \mathrm{FeSO}_{4}$-EDTA, $0.15 \mathrm{ml}$ of $10 \mathrm{mM}$ hydrogen peroxide, $0.525 \mathrm{ml}$ of distilled water and $0.075 \mathrm{ml}(20-120 \mu \mathrm{g} / \mathrm{ml})$ of extracts solution in a tube. The reaction was started by the addition of hydrogen peroxide. After incubation at $37^{\circ} \mathrm{C}$ for $4 \mathrm{~h}$, the reaction was stopped by adding $0.75 \mathrm{ml}$ of $2.8 \%$ $(\mathrm{w} / \mathrm{v})$ trichloroacetic acid and $0.75 \mathrm{ml}$ of $1.0 \%(\mathrm{w} / \mathrm{v})$ of thiobarbituric acid. The mixture was boiled for $10 \mathrm{~min}$, cooled in ice and then measured at $520 \mathrm{~nm}$. The reaction mixture not containing extracts was used as the control. Trolox, ascorbic acid, BHT and BHA (20-120 $\mu \mathrm{g} / \mathrm{ml})$ were used as standard antioxidants. The scavenging activity on hydroxyl radicals was expressed as:

The scavenging activity on hydroxyl radicals $=$

$$
\left[\frac{\left(A_{0}-A_{1}\right)}{A_{0} \times 100}\right]
$$

Where $\mathrm{A}_{0}$ is the absorbance of the control reaction and $A_{1}$ is the absorbance in the presence of extracts.

\section{Data Analysis}

Anti-inflammatory experimental data obtained from 'test' rats treated with ethanolic and aqueous extracts of Moringa peregrina and diclofenac, as well as those obtained from distilled water-treated 'control' rats, were pooled and expressed as means $( \pm \mathrm{SD})$. The differences 
between the plant's extracts and diclofenac-treated 'test' means, and distilled water-treated 'control' means, were analyzed statistically by one way analysis of variance (ANOVA; $95 \%$ confidence interval), followed by TukeyKramer's multiple comparison test to assess the level of significance of the differences between the 'test' and 'control' group data means. Values of $p \leq 0.05$ were taken to imply statistical significance.

\section{RESULTS}

Injections of fresh egg albumin $(0.5 \mathrm{ml} / \mathrm{kg})$ provoked marked, time-related and progressive increases in the hind paw diameters of the 'control', untreated rats. Although pedal inflammation (oedema) was always evident within 5-8 min following fresh egg albumin $(0.5 \mathrm{ml} / \mathrm{kg})$ injection, maximal swelling and/ or oedema occurred approximately 90 minutes following fresh egg albumin administration. Ethanolic and aqueous extracts of Moringa peregrina (100-300 mg/kg i. p.) also produced dose-related, significant reductions $(p<0.05-0.001)$ in the fresh egg albumin-induced acute inflammation of the rat hind paw (Table 1). Ethanolic and aqueous extracts $(300 \mathrm{mg} / \mathrm{kg}$ ) reduced inflammation by $81.01 \%$ and $72.69 \%$, respectively at the third hour. A non-steroidal drug, diclofenac $(100 \mathrm{mg} / \mathrm{kg})$ exhibited anti-inflammatory effect with a maximum response $100 \%$ inhibition at the third hour. Distilled water $(3 \mathrm{ml} / \mathrm{kg}$ i. p.) treatment alone has no anti-inflammatory effect on rat paw oedema induced by fresh egg albumin.

Figure 1 shows the reducing power of Moringa peregrina ethanolic and aqueous extracts. The reducing power of the two extracts increased with increasing concentration. Based on a comparison of the absorbance at $700 \mathrm{~nm}$, the reducing power of ethanolic and aqueous extracts at a concentration of $20 \mu \mathrm{g} / \mathrm{ml}$ was similar to that of $\alpha$-tocopherol at $20 \mu \mathrm{g} / \mathrm{ml}$. This indicates that Moringa peregrina extracts was electron donors and could also react with free radicals, converting them to more stable products and terminate the radical chain reaction. Also, $140 \mu \mathrm{g} / \mathrm{ml}$ is the best concentration which exhibits the most reducing power. The reducing power of the two extracts and both standards decreased in the order of ethanolic extract $>\alpha$-tocopherol $>$ aqueous extract $>$ $\mathrm{BHA}>\mathrm{BHT}$.

Figure 2a, b shows the chelating effect of ethanolic and aqueous extracts, respectively at 0.5, 1.0, 1.25 and $1.50 \mathrm{mg} / \mathrm{ml}$ concentration. The chelating activity of samples increased with increasing incubation times with $\mathrm{FeCl}_{2}$. Also, the chelating activities of ethanolic and aqueous extracts at a concentration of $1.50 \mathrm{mg} / \mathrm{ml}$ are $60 \%$ and $37 \%$, respectively at $90 \mathrm{~min}$. In addition, no change in chelating activity of $1.50 \mathrm{mg} / \mathrm{ml}$ ethanolic extract with increasing the incubation times with $\mathrm{FeCl}_{2}$ more than $90 \mathrm{~min}$. However, the chelating activity of ethanolic extract of $1.0 \mathrm{mg} / \mathrm{ml}$ was nearly equal to EDTA

Table 1. Anti-inflammatory activity of ethanolic and aqueous extracts of Moringa peregrina (100-300 mg/kg i. p.) and diclofenac (100 mg/kg i. p.) on rat paw oedema induced by fresh egg albumin $(0.5 \mathrm{ml} / \mathrm{kg} \mathrm{s}$. p.). Values quoted represent the mean ( \pm SEM) of 8 observations. Percent inhibitions of the egg albumin-induced inflammation by the plant's extract and reference drug used are indicated as (\%)

\begin{tabular}{|c|c|c|c|c|c|}
\hline \multirow{2}{*}{$\begin{array}{c}\begin{array}{c}\text { Experimental Group } \\
\text { Dose (i.p.) }\end{array} \\
\text { Control Group A (untreated) }\end{array}$} & \multicolumn{4}{|c|}{ Time (in min) and paw diameter (in mm) 306090120} & \multirow{2}{*}{$\begin{array}{c}180 \\
11.35 \pm 0.06\end{array}$} \\
\hline & $10.45 \pm 0.04$ & $12.50 \pm 0.05$ & $15.65 \pm 0.07$ & $14.75 \pm 0.06$ & \\
\hline $\begin{array}{l}\text { Control Group B (distilled } \\
\text { water-treated) 3ml/kg }\end{array}$ & $10.50 \pm 0.035$ & $12.46 \pm 0.06$ & $15.66 \pm 0.04$ & $14.80 \pm 0.071$ & $11.33 \pm 0.04$ \\
\hline Ethanolic extract $(100 \mathrm{mg} / \mathrm{kg})$ & $9.82 \pm 0.07^{*}$ & $10.98 \pm 0.08^{*}$ & $12.18 \pm 0.07^{*}$ & $9.26 \pm 0.06^{*}$ & $6.53 \pm 0.04^{\star *}$ \\
\hline Ethanolic extract $(200 \mathrm{mg} / \mathrm{kg})$ & $9.20 \pm 0.07^{\star}$ & $9.64 \pm 0.08^{*}$ & $9.12 \pm 0.08^{*}$ & $8.00 \pm 0.07^{\star \star}$ & $5.12 \pm 0.04^{\star *}$ \\
\hline Ethanolic extract $(300 \mathrm{mg} / \mathrm{kg})$ & $5.40 \pm 0.06^{\star \star}$ & $4.98 \pm 0.05^{\star \star}$ & $3.66 \pm 0.05^{\star \star \star}$ & $2.80 \pm 0.04^{\star \star \star}$ & $2.80 \pm 0.04^{\star * *}$ \\
\hline Aqueous extract $(100 \mathrm{mg} / \mathrm{kg})$ & $10.72 \pm 0.08^{*}$ & $8.08 \pm 0.08^{*}$ & $7.39 \pm 0.05^{\star \star}$ & $7.15 \pm 0.05^{\star \star}$ & $6.05 \pm 0.06^{\star *}$ \\
\hline Aqueous extract $(200 \mathrm{mg} / \mathrm{kg})$ & $8.10 \pm 0.05^{\star}$ & $7.42 \pm 0.05^{\star \star}$ & $7.15 \pm 0.05^{\star \star}$ & $5.72 \pm 0.04^{\star \star}$ & $4.05 \pm 0.04^{* * *}$ \\
\hline Aqueous extract $(300 \mathrm{mg} / \mathrm{kg})$ & $8.25 \pm 0.22^{*}$ & $7.45 \pm 0.15^{\star \star}$ & $7.10 \pm 0.08^{\star \star}$ & $6.34 \pm 0.06^{\star \star}$ & $3.10 \pm 0.03^{* \star *}$ \\
\hline Diclofenac \# & $4.10 \pm 0.06^{\star * *}$ & $3.64 \pm 0.05^{\star \star \star}$ & $2.80 \pm 0.04^{* * *}$ & $1.32 \pm 0.03^{\star * *}$ & $0.00 \pm 0.00^{\star * *}$ \\
\hline
\end{tabular}

\#Diclofenac is used as a reference

Experimental groups were compared to control group. Values are given as mean \pm SD for groups of six animals each. $*$ Significant at $P<0.05 * *$ Significant at $P<0.01, * * *$ Significant at $P<0.001$ 
at $0.037 \mathrm{mg} / \mathrm{ml}(43.67 \%)$ for an incubation time of $10 \mathrm{~min}$. This indicates that the chelating property of the samples on $\mathrm{Fe}^{2+}$ ions may afford protection against oxidative damage.
The DPPH' radical scavenging effects of ethanolic and aqueous extracts are presented in Figure 3 and showed appreciable free radical scavenging activities. The free radical scavenging activity of the extracts was



Figure 1. Reducing power of ethanolic and aqueous extracts, BHA, BHT and $\alpha$-tocopherol.

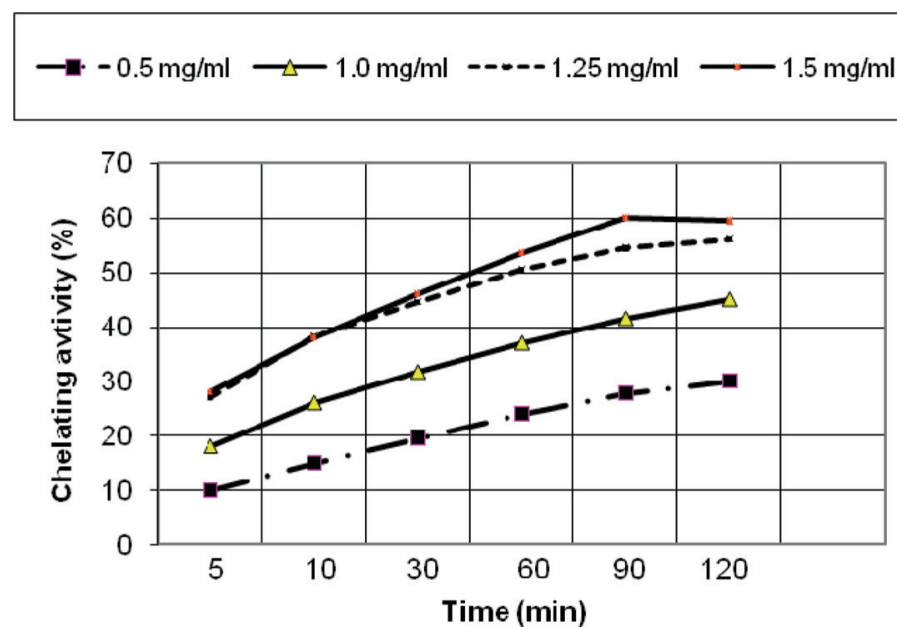

Figure 2a. Chelating effects of different concentrations of ethanolic extract on $\mathrm{Fe}^{2+}$ ions at different incubation times with $\mathrm{FeCl}_{2}$.

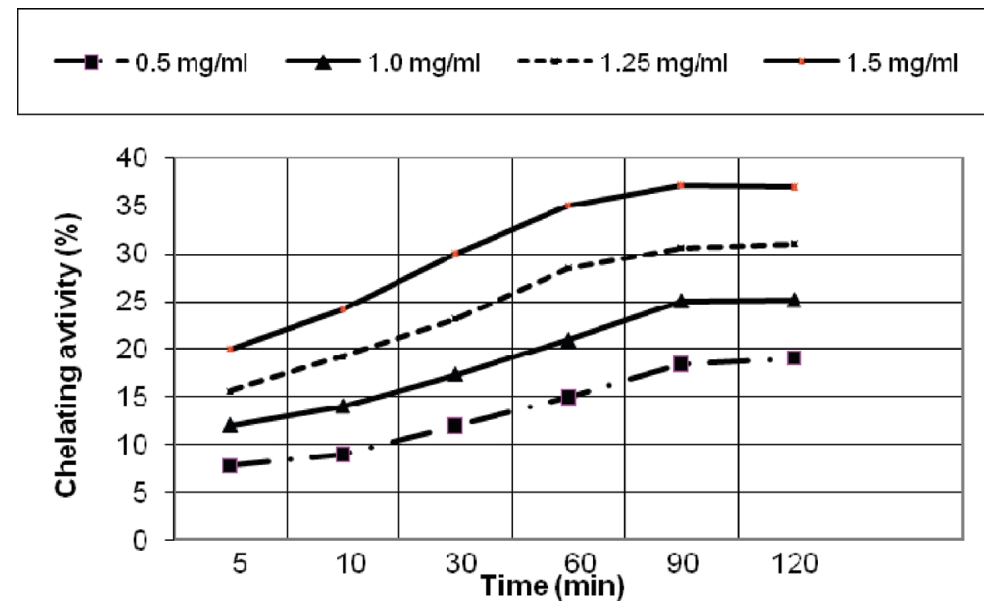

Figure 2b. Chelating effects of different concentrations of aqueous extract on $\mathrm{Fe}^{2+}$ ions at different incubation times with $\mathrm{FeCl}_{2}$. 
compared to trolox, as a synthetic antioxidant. Ethanolic extract of Moringa peregrina at $6 \mathrm{mg} / \mathrm{ml}$ had the highest radical scavenging activity when compared with $0.06 \mathrm{mg} / \mathrm{ml}$ trolox. But the radical scavenging activity of aqueous extract of $6 \mathrm{mg} / \mathrm{ml}$ was nearly equal to trolox at $0.06 \mathrm{mg} / \mathrm{ml}(72 \%)$.

The effects of $100 \mathrm{mg} / \mathrm{l}$ of ethanolic and aqueous extracts Moringa peregrina on peroxidation of linoleic acid emulsion are shown in Figure 4. The extracts showed higher antioxidant activity when compared to $\alpha$-tocopherol, trolox, BHA, and BHT. Total antioxidant activity of Moringa peregrina extracts and both standards decreased in the order of ethanolic extract $>\alpha$-tocopherol $>$ aqueous extract $>$ trolox $>$ BHT $>$ BHA. Also, the antioxidant activity of aqueous extract was nearly equal to $\alpha$-tocopherol.

Figure 5 shows the superoxide radical scavenging activity of ethanolic and aqueous extracts Moringa peregrina at different concentrations $0.1,0.5$ and $1.0 \mathrm{mg} / \mathrm{ml}$ in comparison to the same amount of $\mathrm{BHA}$, trolox and ascorbic acid. At $1.0 \mathrm{mg} / \mathrm{ml}$ concentration, ethanolic and aqueous extracts of Moringa peregrina showed higher superoxide radical scavenging activity than BHA and nearly equal to trolox and ascorbic acid. The superoxide radical scavenging activity of the two extracts and both standards decreased in the order of ascorbic acid $>$ trolox $>$ ethanolic extract $>$ aqueous extract $>$ BHA.

Figure 6 presents the scavenging activity of the extracts on $\mathrm{H}_{2} \mathrm{O}_{2}$. The results are compared with BHA, BHT, and $\alpha$-tocopherol as standards. Moringa peregrina ethanolic and aqueous extracts were capable of scavenging activity in a concentration-dependent manner. At $100 \mu \mathrm{g} / \mathrm{ml}$, ethanolic and aqueous extract exhibited $79 \%$ and $65 \%$, respectively. On the other hand, BHT, BHA, and $\alpha$-tocopherol exhibited $28 \%, 35 \%$, and $75 \%$, respectively, of $\mathrm{H}_{2} \mathrm{O}_{2}$ scavenging activity at the same concentration.

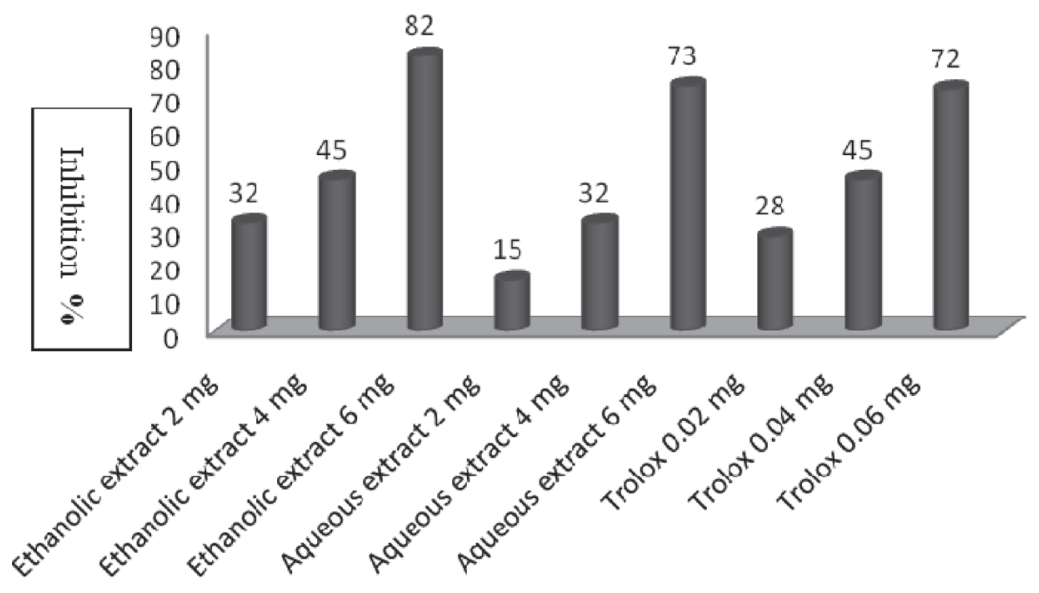

Figure 3. Scavenging activities of different concentrations of ethanolic and aqueous extracts and trolox against the 1,1-diphenyl-2-picryl-hydrazil (DPPH) radical.

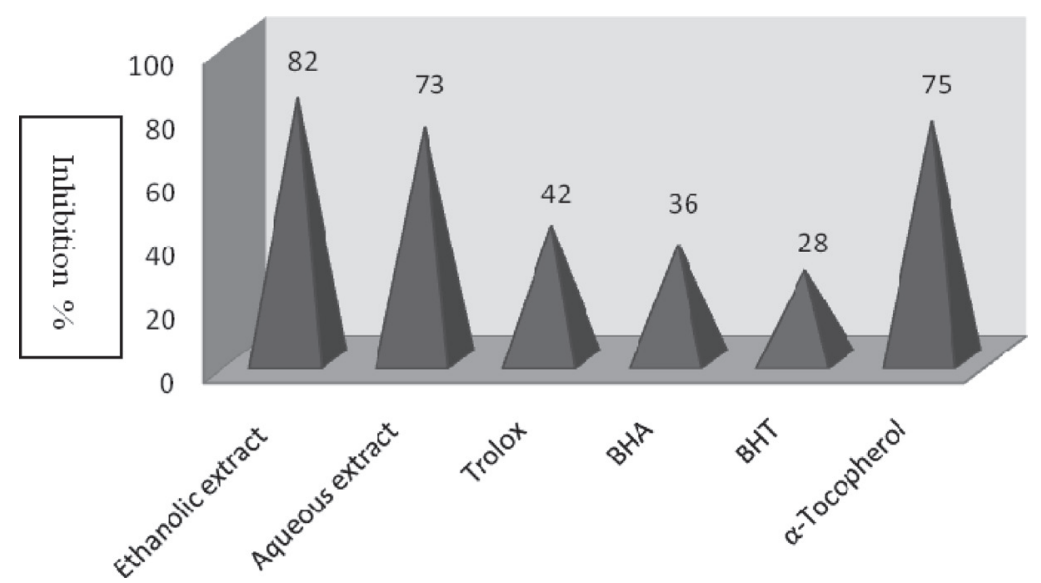

Figure 4. Total antioxidant activities of ethanolic and aqueous extracts, $\alpha$-tocopherol, trolox and BHA, BHT (100 mg/l concentration) on peroxidation of linoleic acid emulsion. 
Figure 7 shows the hydroxyl radical scavenging effects determined by the 2-deoxyribose oxidation method. The scavenging effect of Moringa peregrina ethanolic and aqueous extracts on hydroxyl radical was concentration dependent. At 20 and $40 \mathrm{ug} / \mathrm{ml}$ the two extracts have the same hydroxyl radical scavenging activity. Also, at

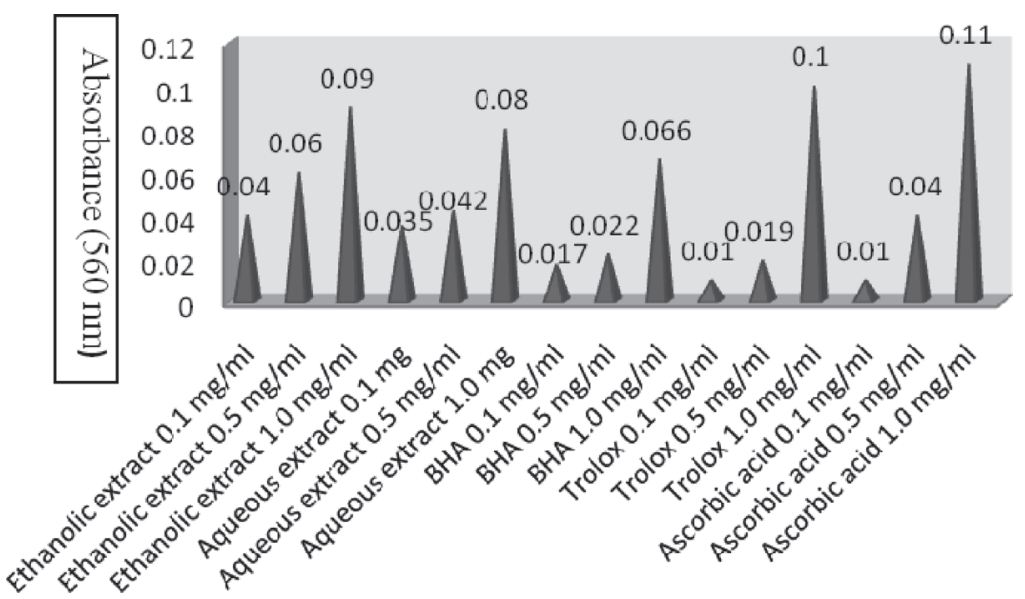

Figure 5. Superoxide radical scavenging activity of ethanolic and aqueous extracts, trolox, ascorbic acid and $\mathrm{BHA}$ at different concentrations.

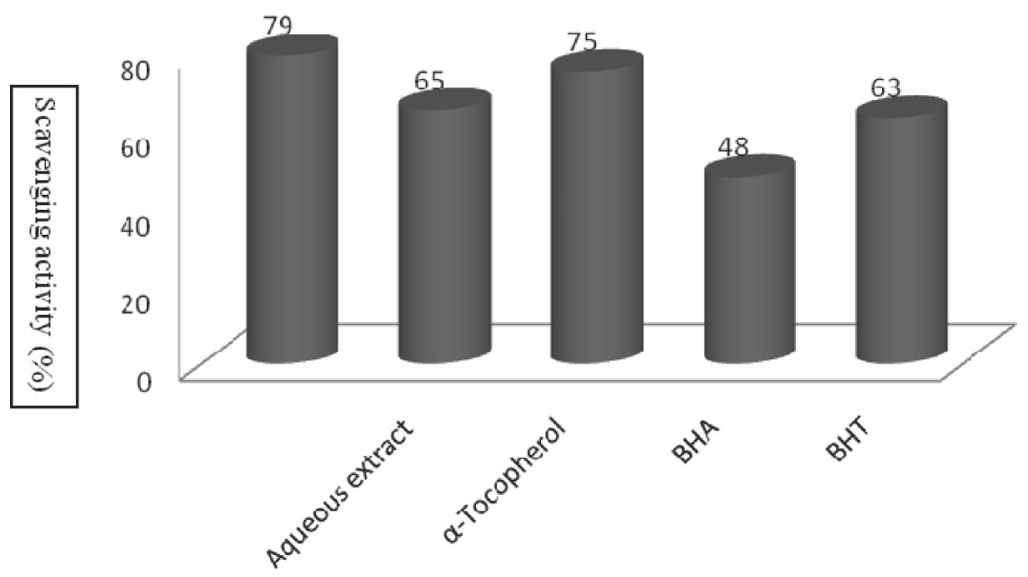

Figure 6. Hydrogen peroxide scavenging activity of ethanolic and aqueous extracts, $\alpha$-tocopherol, BHT and BHA at $100 \mu \mathrm{g} / \mathrm{ml}$ concentration.



Figure 7. Hydroxyl radical scavenging activities of ethanolic and aqueous extracts, trolox, ascorbic acid, BHT and BHA at different concentrations. 
$20-140 \mu \mathrm{g} / \mathrm{ml}$ concentrations, ethanolic extract exhibited higher hydroxyl radical scavenging activity than ascorbic acid. Among the oxygen radicals, hydroxyl radical is the most reactive chemical species known. The hydroxyl radical induces some oxidative damage to biomolecules such as all proteins, DNA, nucleic acid. The hydroxyl radical scavenging activity of the two extracts and both standards decreased in the order of ethanolic extract $>$ aqueous extract $>$ trolox $>$ ascorbic acid $>$ BHT $>$ BHA.

\section{DISCUSSION}

Inflammation, which is a pattern of response to injury, involves the accumulation of cells and exudates in irritated tissues that allows protection from further damage. Inflammation has been studied for thousands of years in an attempt to combat its effects on the body. Experimental evidence obtained in the present study indicates that the ethanolic and aqueous extracts of Moringa peregrina (100-300 mg/kg i.p.) dose-dependently and significantly delayed $(p<0.05-0.001)$ the inflammation. Diclofenac, a non-steroidal anti-inflammatory drug (NSAID), is commonly employed in the treatment and/ or management of rheumatoid arthritis, osteo-arthritis and ankylosing spondylitis ${ }^{[38]}$ and for its anti-inflammatory and analgesic effects. ${ }^{[39]}$ Diclofenac reduces inflammation, swelling and arthritic pain by inhibiting prostaglandins synthesis and/or production. ${ }^{[40]}$ The drug also affects polymorphonuclear leukocytes function in vitro, thereby reducing chemotaxis, superoxide toxic radical formation, oxygen-derived free radical generation and neutral protease production. ${ }^{[41]}$ Diclofenac has also been reported to suppress inflammation induced by various phlogistic agents in experimental animal models. ${ }^{[42]}$ Although the anti-inflammatory and antioxidant effect of ethanolic and aqueous extracts of Moringa peregrina could not be discussed in any article before that and our study is the first type in this kind, the results obtained suggest that Moringa peregrina extracts may produce its antiinflammatory effect due to the presence of tannins, ${ }^{[43]}$ flavonoids ${ }^{[44]}$ (figure 8), saponins, ${ }^{[45]}$ unsaturated sterols and/or triterpenes ${ }^{[15]}$ figure 9 . In vivo and in vitro antiinflammatory effects have been reported for several flavonoids. Thus, some flavones have been found to be active in different experimental models. B-ring substituted flavones of this type are capable of inhibiting cottonpellet induced granuloma and carrageenan edema in rats and TPA-mouse ear edema. ${ }^{[4]}$ Nevertheless, the influence of Moringa peregrina extracts on the inhibition of inflammation is not yet completely understood.

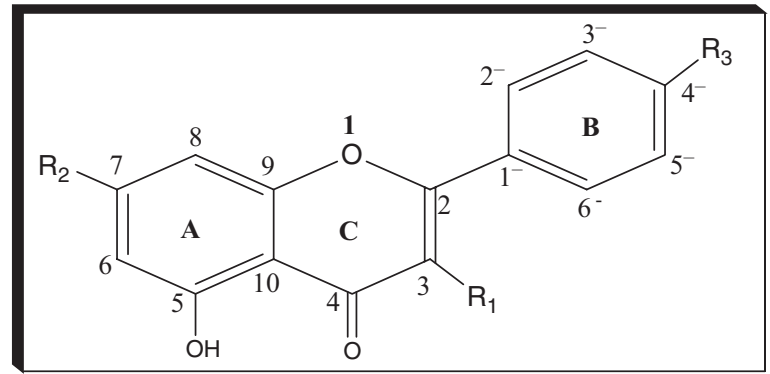

Compound 1: kaempferol 3-0-(2",3"-diacetylglucoside), $\mathrm{R}_{1}=\mathrm{O}-2$ ", 3"-Diacetylglucoside, $\mathrm{R}_{2}=\mathrm{OH}, \mathrm{R}_{3}=\mathrm{OCH}_{3}$ Compound 2: kaempferol 3-0-(2"-0-galloylrhamnoside), $\mathrm{R}_{1}=O$-[Glucosyl-( $\left.1^{\prime \prime \prime} \rightarrow 2^{\prime \prime}\right)$ ]-[rhamnosyl $\left(1^{\prime \prime \prime \prime} \rightarrow 6^{\prime \prime}\right)$-glucoside, $\mathrm{R}_{2}=$ O-rhamnose, $\mathrm{R}_{3}=\mathrm{OH}$

\section{Compound 3: kaempferol 3-0-(2"-0-galloylrutinoside)} -7-0- $\alpha$-rhamnoside,

$\mathrm{R}_{1}=\mathrm{O}-\left(2\right.$ "-Galloylrhamnoside), $\mathrm{R}_{2}=\mathrm{OH}, \mathrm{R}_{3}=\mathrm{OCH}_{3}$

Figure 8. structure of flavonoid derivatives from Moringa(11)

Saponins are a group of glycosides found in many plants. Saponins can be classified into two groups based on the nature of their aglycone skeleton. One group consists of the steroidal saponins and the other group consists of the triterpenoid saponins. ${ }^{[47]}$ There are a number of saponins isolated from various plants which have anti-inflammatory activity. ${ }^{[48]}$ The presence of saponins in Moringa peregrina extracts may produce its anti-inflammatory effect.

\section{Evaluation of Antioxidant Property}

1. Determination of reducing power: The effects of free radicals on human beings are closely related to toxicity, disease and aging (49). Most living species have an efficient defense system to protect themselves against the oxidative stress induced by Reactive Oxygen Species (ROS). ${ }^{[50]}$ Recent investigations have shown that the antioxidant properties of plants could be correlated with oxidative stress defense and different human diseases. ${ }^{[5-8]}$ Human organism possesses systems controlling oxidation processes posing a threat to structures and functions of cells. Three defense mechanisms has been developed, ${ }^{[51]}$ including: prevention of reactions of reactive oxygen species with biologically-significant compounds, breaking free-radical chain reactions and undesirable non-radical oxidation reactions, scavenging the products of free radicals reactions with biological substances and repair of damages. Flavonoid's activity as antioxidants refers to their ability to transfer a hydrogen atom or an electron and to the possibility of their interactions with other 
antioxidants. ${ }^{[52]}$ The reducing power has been used as one of the antioxidant capability indicators of plants. ${ }^{[53]}$ In the reducing power assay, the presence of reductants (antioxidants) in the tested extracts resulted in the reduction of the $\mathrm{Fe}^{3+} /$ ferricyanide complex to the ferrous form $\left(\mathrm{Fe}^{2+}\right)$ figure 1. The amount of $\mathrm{Fe}^{2+}$ complex can therefore be monitored by measuring the formation of Perl's Prussian Blue at 700 nm. ${ }^{[1]}$

The results in figure 1 the reducing power of ethanolic and aqueous extracts from Moringa peregrina. The reducing power of all the extracts increased with increasing concentration. Based on a comparison of the absorbance at $700 \mathrm{~nm}$, the reducing power of Moringa peregrina extracts at a concentration of $20 \mu \mathrm{g} / \mathrm{ml}$ was similar to that of $\alpha$-tocopherol at $20 \mu \mathrm{g} / \mathrm{ml}$. This indicates that the extracts of Moringa peregrina were electron donors and could also react with free radicals, converting them to more stable products and terminate the radical chain reaction.

The presence of flavonoids in Moringa peregrina extracts the extracts, which have been reported to possess several biological properties. Despite the similarity between flavonoid structures, the biological properties vary considerably with only minor modifications in their structure. The number and specific positions of hydroxyl groups and the nature of the substitutions determine whether flavonoids function as strong antioxidative, ${ }^{[54]}$ anti-inflammatory, antiproliferative ${ }^{[55]}$ or enzyme modulating agents. Hydroxylation of the B-ring, where a catechol group is the key to the flavonoid activity, coupled with a 2, 3 double bond in conjugation with a 4-oxo function (carbonyl group) in the $\mathrm{C}$-ring. ${ }^{[54]}$

The antioxidant properties of Moringa peregrina flavonoids resulted from their chemical structure: 4'-hydroxyl system in the $\mathrm{B}$ ring, reciprocal configuration of the double bond C2-C3 and the 4-carbonyl group of the $\mathrm{C}$ ring, and configuration of the 5-hydroxyl group of the A ring ${ }^{[56]}$ (Figure 8). All the mentioned structural conditions may be found in Moringa peregrina flavonoid; kaempferide flavonoids which, in the in vitro systems efficiently scavenges hydroxyl radical $\left(\mathrm{OH}^{\circ}\right)$, superoxide radical $\left(\mathrm{LOO}^{\circ}\right)$, superoxide anion radical $\left(\mathrm{O}_{2}{ }^{\circ}\right)$, singlet oxygen $\left({ }^{1} \mathrm{O}_{2}\right)$, and nitrogen oxide $\left(\mathrm{NO}^{\circ}\right)$.

\section{Determination of chelating activity on $\mathrm{Fe}^{2+}$ : Iron} is the most important lipid oxidation pro-oxidant due to its high reactivity. The ferrous state of iron can stimulate lipid peroxidation by the Fenton type reaction and also accelerates peroxidation by decomposing lipid hydroperoxides into peroxyl and alkoxyl radicals that can themselves abstract hydrogen and perpetuate the chain reaction of lipid peroxidation. The $\mathrm{Fe}^{3+}$ ion also produces radicals from peroxides, although the rate is ten times less than that of the $\mathrm{Fe}^{2+}$ ion. The $\mathrm{Fe}^{2+}$ ion is the most powerful pro-oxidant among the various species of metal ions. ${ }^{[57]}$ Ferrozine, a chelating reagent, was used to indicate the presence of chelator in the reaction system. Ferrozine forms a complex with free $\mathrm{Fe}^{2+}$ but not with $\mathrm{Fe}^{2+}$ bound by extracts. In the presence of chelating agents, the complex formation of ferrous iron and ferrozine is disrupted, resulting in a decrease in the red color of the complex. Measurement of color reduction therefore allows the metal chelating activity of the coexisting chelator to be estimated. ${ }^{[58]}$ The purpose of the test of ferrous ion chelating activity was to determine the capacity of Moringa peregrina extracts to bind the ferrous ion catalyzing oxidation. The ferrous ion chelating effect of Moringa peregrina extracts is presented in Figure 2a-b. The ethanolic and aqueous extracts at $1.5 \mathrm{mg} / \mathrm{ml}$ concentration showed $55 \%$ and $35 \%$ chelating effect on ferrous ions at an incubation time of $60 \mathrm{~min}$, respectively. The chelating activity of samples increased with increasing incubation times with $\mathrm{FeCl}_{2}$. At the same amounts, ethanolic exhibited higher chelating activity on $\mathrm{Fe}^{2+}$ than aqueous extracts. However, the chelating activity of ethanolic extract of $1.0 \mathrm{mg} /$ $\mathrm{ml}$ was nearly equal to EDTA at $0.037 \mathrm{mg} / \mathrm{ml}(43.67 \%)$ for an incubation time of $90 \mathrm{~min}$. This indicates that the chelation property of the samples on $\mathrm{Fe}^{2+}$ ions may afford protection against oxidative damage.

\section{Determination of free radical-scavenging} activity: Free radicals are known to be a major factor in biological damages, and $\mathrm{DPPH}^{\circ}$ has been used to evaluate the free radical-scavenging activity of natural antioxidants. ${ }^{[26]} \mathrm{DPPH}^{\circ}$, which is a molecule containing a stable free radical with a purple color, changes into a stable compound with a yellow color by reacting with an antioxidant which can donate an electron to $\mathrm{DPPH}^{\circ}$, Figure 3. In such case, the purple color typical of the free DPPH ${ }^{*}$ radical decays, a change which can be followed either spectrophotometrically $(517 \mathrm{~nm})$. The proton radical scavenging action is known as an important mechanism of antioxidation. 1,1-Diphenyl-2-picrylhydrazil $\left(\mathrm{DPPH}^{\circ}\right)$ is used as a free radical to evaluate the antioxidative activity of some natural sources. ${ }^{[1]}$ From these results, it can be stated that Moringaperegrina extracts have the ability to scavenge free radicals and could serve as a strong free radical inhibitor or scavenger according 
to trolox. On the other hand, Moringa peregrina flavonoids may be particularly important in protecting cellular DNA, lipids and proteins from free radical damage. It has been reported that the antioxidant activity of flavonoids may result from the neutralization of free radicals initiating oxidation processes, or from the termination of radical chain reactions, due to their hydrogen donating ability. ${ }^{[9]} \mathrm{It}$ is also known that the antioxidant activity of polyphenolic compounds is closely associated with their structures, such as substitutions on the aromatic ring and side chain structure. Their accessibility to the radical centre of $\mathrm{DPPH}^{*}$ could also influence the order of the antioxidant power. Free radical scavenging activity of polyphenolic compounds is believed to be influenced by the number and position of phenolic hydrogen in their molecules. ${ }^{[54]}$ It is also proposed that the higher antioxidant activity is related to the greater number of hydroxyl groups on the flavonoid nucleus. ${ }^{[60]}$

\section{Determination of total antioxidant activity} determination: The total antioxidant activity of Moringa peregrina extracts was determined by the thiocyanate method in linoleic acid emulsion. The antioxidative activities of Moringa peregrina ethanolic and aqueous extracts were compared with commercial antioxidants such as $\alpha$-tocopherol (Toc), BHT, BHA and trolox. Total antioxidant activity of Moringa peregrina extracts and both standards decreased in the order of ethanolic extract $>\alpha$-tocopherol $>$ aqueous extracts $>$ trolox $>$ $\mathrm{BHA}>\mathrm{BHT}$ figure 4 .

\section{Determination of superoxide radical scavenging}

activity: Superoxide radical, known to be very harmful to cellular components as a precursor of the more reactive oxygen species, contributes to tissue damage and various diseases. In a biological system, its toxic role can be eliminated by superoxide dismutase. ${ }^{[1]}$ The radicals may also play an important role during the peroxidation of unsaturated fatty acids and other potential susceptible substances. ${ }^{[61]}$ The superoxide radical scavenging activity of Moringa peregrina extracts and both standards decreased in the order of ascorbic acid $>$ trolox $>$ ethanolic extract $>$ aqueous extracts $>$ BHA figure 5. In the terms of molecules of superoxide radical, Moringa peregrina extracts were equivalent to ascorbic acid. The reaction mechanism of superoxide radical with superoxide radical can be explained by twosteps reaction: in the first step, one molecule of superoxide radical reacts with one molecule of ascorbic acid produce ascorboxy radical and oxide radical. Then, one ascorboxy radical reacts with another molecule of oxide radical to form ascorboxyl-quinone. Hence, one molecules of superoxide radical are reduced by one molecule of ascorbic acid.

\section{Determination of hydrogen peroxide scavenging} activity: Hydrogen peroxide is an intermediate during endogenous oxidative metabolism and mediates radical oxygen formation such as $\mathrm{OH}$, which may be used to predict the scavenging capability of antioxidants in biological systems. ${ }^{[32]} \mathrm{H}_{2} \mathrm{O}_{2}$ has only a weak activity to initiate lipid peroxidation, but its activity as an active oxygen species comes from its potential to produce the highly reactive hydroxyl radical through the Fenton reaction. These results in figure 6 showed that Moringa peregrina extracts have a strong $\mathrm{H}_{2} \mathrm{O}_{2}$ scavenging activity. At $100 \mu \mathrm{g} / \mathrm{ml}$ concentration, $\mathrm{H}_{2} \mathrm{O}_{2}$ scavenging activity of extracts and both standards decreased in the order of ethanolic extract $>\alpha$-tocopherol $>$ aqueous extract $>\mathrm{BHT}>\mathrm{BHA}$. The mechanism of Moringa peregrina extracts antioxidant activity was designed by hydrogen donation to free radicals and formation of a complex between the lipid radical and the antioxidant radical (Moringa peregrina polyphenols, free radical acceptor). In the terms of molecules of hydrogen peroxide, resveratrol was equivalent to $\alpha$-tocopherol. The reaction mechanism of hydrogen peroxide with $\alpha$-tocopherol can be explained by two-steps reaction: in the first step, one molecule of hydrogen peroxide reacts with one molecule of $\alpha$-tocopherol produce $\alpha$-tocopheroxy radical and ${ }^{-} \mathrm{OH}$. Then, one $\alpha$-tocopheroxy radical reacts with another molecule of hydroxyl radical to form $\alpha$-tocopherolquinone. Hence, one molecules of hydrogen peroxide are reduced by one molecule of $\alpha$-tocopherol.

\section{Determination of hydroxyl radical scavenging} activity: The scavenging effect of ethanolic and aqueous extracts of Moringa peregrina on hydroxyl radical was concentration dependent. At 20-140 $\mu \mathrm{g} / \mathrm{ml}$ concentrations, ethanolic and aqueous extracts of Moringa peregrina exhibited lower hydroxyl radical scavenging activity than ascorbic acid. At 20 and $40 \mu \mathrm{g} / \mathrm{ml}$ concentrations, ethanolic and aqueous extracts of Moringa peregrina showed the same hydroxyl radical scavenging activity. At $60-140 \mu \mathrm{g} / \mathrm{ml}$ concentrations, ethanolic extract of Moringa peregrina showed higher hydroxyl radical scavenging activity than aqueous.

The antioxidant capacity of the Moringa peregrina extracts is mainly dependent on phenolic compounds. 
The presence of phenolics constitute; tannins, ${ }^{[43]}$ flavonoids ${ }^{[4]}$ figure 8 , saponins, ${ }^{[45]}$ unsaturated sterols and/or triterpenes ${ }^{[15]}$ figure 9 , all of these major groups of compounds acting as primary antioxidants or free radical terminators, it was reasonable to determine their total amount in the Moringa peregrina plant extracts. In this study, the phenols contain hydroxyls that are responsible for the radical scavenging effect mainly due to redox properties. ${ }^{[62]}$ According to our study, the high phenolic content in of Moringa peregrina can explain its high free radical scavenging activity.

The anti-inflammatory and antioxidant activities of Moringa peregrina seeds ethanolic and aqueous extracts have not been reported earlier to our knowledge and this study is might be the first observation of that kind.

In conclusion, the methods selected to assess the antioxidant activity of the Moringa peregrina ethanolic and aqueous extracts roughly represented different systems like reducing power, chelating activity on $\mathrm{Fe}^{2+}$, free radical-scavenging, total antioxidant, superoxide radical scavenging, hydrogen peroxide scavenging and hydroxyl radical scavenging activities. The present study showed that the effects of antioxidative activity of Moringa peregrina extracts depend on the presence of bioactive polyphenolics constitute; tannins, flavonoids, saponins, unsaturated sterols and/or triterpenes.

\section{REFERENCES}

1. Chung Y, Chen S, Hsu C, Chang $C$ and Chou S. Studies on the antioxidative activity of Graptopetalum paraguayense E. Walther. Food Chem. 2005; 91:419-423.

2. Halliwell B, Gutteridge JMC and Cross CE. Free radicals, antioxidants and human diseases: where are we now. J Lab Clin Med.1992; 119:598-620.

3. Zhao B, Li X, He R, Cheng S and Xin W. Scavenging effect of extracts of green tea and natural antioxidants on active oxygen radicals. Cell Biophys. 1989; 14:175-185.

4. Juntachote $T$ and Berghofer E. Antioxidative properties and stability of ethanolic extracts of Holy basil and Galangal. Food Chem. 2005; 92:193-202.

5. Hussein MA. Antidiabetic and antioxidant activity of Jasonia Montana extract in streptozotocin-induced diabetic rats. Saudi Pharmaceutical Journal. 2008; 16:214- 21.

6. Hussein MA and Abdel-Gawad SA. Protective effe.ct of Jasonia montan against ethinylestradiol-induced cholestasis in rats. Saudi Pharmaceutical Journal. 2010; 18:35-45.

7. Hussein MA and Farghaly HS. Protective effects of Jasonia montana against Lipid peroxidation in liver and kidney of ironoverloaded rats. Australian Journal of Basic and Applied Sciences. 2010; 4:2004-2012.

8. Hussein MA. Anti-obesity, antiatherogenic, anti-diabetic and antioxidant activities of $\mathrm{J}$. montana ethanolic formulation in obese diabetic rats fed high-fat diet. Free Radicals and Antioxidants. 2011; 1:51-62.
9. Brit,DF, Hendrich $S$ and Wang S. Dietary agents in cancer prevention: flavonoids and isoflavonoids, Pharmacol Therapeut. 2001; 90:157-177.

10. Yang CS, Landau JM, Huang MT and Newmark HL. Inhibition of carcinogenesis by dietary polyphenolic compounds, Annu Rev Nutr. 2001; 12:381-406.

11. Manguro LOA and Lemmen P. Phenolics of Moringa oleifera Lam. leaves. Natural Product Research. 2007; 21:56-68.

12. Parvathy MVS and Umamaheshwari A. Cytotoxic effect of Moringa oleifera Lam. leaf extracts on human multiple myeloma cell lines. Trends in Medical Research. 2007; 2:44-50.

13. Okuda T, Baes AU, Nishijima $W$ and Okada M. Isolation and characterization of coagulant extracted from Morringa oleifera seed by salt solution. Water Res. 2001; 35:405-410.

14. Selvakumar D and Natarajan P. Hepatoprotective activity of Moringa oleifera Lam. leaves in carbon tetrachloride induced hepatotoxicity in albino rats. Phcog. mag. 2008; 13:97-98.

15. Yammuenart D, Chavasiri $W$ and Pongrapeeporn K. Chemical constituents of Moringa oleifera Lam. The Science Forum.2008; 3:80-81.

16. Ferreira PMP, Farias D F, Oliveira JT and Carvalho AU. Moringa oleifera Lam.: bioactive compounds and nutritional potential. Rev. Nutr. 2008; 21:35-44.

17. Tsaknis J, Lalas S, Gergis V, Dourtoglou V, and Spiliotis V. Characterization of Moringa oleifera Lam. seed oil of Kenya. J. Agric. Food Chem. 1999; 47:4495-4499.

18. Anwar F, Latif S, Ashraf M and Gilani AH. Moringa oleifera: a food plant with multiple medicinal uses. Phytother Res. 2007; 21:17-25.

19. Fahey JW. Moringa Oleifera: A review of the medica evidence for its nutritional, therapeutic, prophylactic properties. Trees for life journal. 2005; Part 1.

20. Seshadri S and Nambiar VS. Kanjero Digera arvensis and drumstick leaves (Moringa oleifera): nutrient profile and potential for human consumption. World Rev Nutr Diet. 2003; 91:41-59.

21. Bhuptawat H, Folkard GK and Chaudhari S. Innovative physicochemical treatment of wastewater incorporating Moringa oleifera seed coagulant. J Hazard Matter. 2007; 142:477-482.

22. Sashidhara KV, Rosaiah JN, Tyagi E, Shukla R, Raghubir R and Rajendran SM. Rare dipeptide and urea derivatives from roots of Moringa oleifera as potential anti-inflammatory and antinociceptive agents. 2009; 44:432-6.

23. Rathi BS, Bodhankar SL and Baheti AM. Evaluation of aqueous leaves extract of Moringa oleifera Lam for wound healing in albino rats. Indian J Exp Biol. 2006; 44:898-901.

24. Praveen RB, Kokate CK, Rambhau D, Venkateshwarlu V and Murthy VN. Antihepatotoxic activity of some ayurvedic preparations. Indian J Pharm Sci. 1993; 55:137-140.

25. Fakurazi S, Nanthini $U$ and Hairuszah I. Hepatoprotective and antioxidant action of Moringa oleifera Lam Against acetaminophen induced hepatotoxicity in rats. Int J Pharmacol 2008; 4:270-75.

26. Fakurazi S, Hairuszah I and Nanthini U. Moringa oleifera Lam prevents acetaminophen induced liver injury through restoration of glutathione level. Food Chem Toxicol. 2008; 46:2611-15.

27. Hammerschmidt FJ, Clark AM, Soliman FM, El- Kashoury ESA, Abd El-Kawy MM and El-Fishawy AM. Chemical composition and antimicrobial activity of essential oils of Jasonia candicans and Jasonia montana, Planta Medica. 1993; 59:68-70.

28. Muko KN and Ohiri, FC. A preliminary study on the antiinflammatory properties of Emilia sonchifolia leaf extracts. Fitoterapia. 2000; 71; 65-8. 
29. Ekpendu OT, Akah, PA, Adesomuju AA and Okogun CJ. Anti-inflammatory and antimicrobial activities of Mitracarpus scaber extracts. International Journal of Pharmacognosy. 1994; 32:191-196.

30. Oyaizu M. Studies on products of browning reaction prepared from glucose amine. Jpn. J. Nutr. 1986; 44:307-312.

31. Decker EA and Welch B. Role of ferritin as a lipid oxidation catalyst in muscle food. J. Agr. Food Chem. 1990; 38:674-683.

32. Brand-Williams W, Cuvelier ME and Berset C. Use of a free radical method to evaluate antioxidant activity. Lebensm. Wiss. Technol. 1995; 28:25-32.

33. Takashira M and Ohtake Y.A new antioxidative 1,3-benzodioxole from Melissa officinalis. Planta Med. 1998; 64:555-563.

34. Osawa T and Namiki N. A novel type of antioxidant isolated from leaf wax of Eucalpyptus leaves. Agr. Biol. Chem. 1981; 45:735-742.

35. Liu F, Ooi VFC and Chang ST. Free radical scavenging activity of mushroom polysaccharide extracts. Life Sci. 1997; 60:763-772.

36. Ruch RT, Cheng SJ and Klawnig E. Prevention of cytotoxicity and inhibition of intercellular communication by antioxidant catechins isolated from Chineese green tea. Carcinogenesis. 1989; 10:1003-1009.

37. Chung SK, Osawa,T and Kawakishi S. Hydroxyl radical scavenging effects of species and scavengers from brown mustard (Brassica nigra). Biosci. Biotech. Biochem. 1997; 61:118-123.

38. Brooks PM, Hill W and Geddes R. Diclofenac and ibuprofen in rheumatoid arthritis and osteoarthritis. Medical Journal of Australia, 1980; 1:29-30.

39. Small RE. Drug reviews: Diclofenac sodium. Clinical Pharmacy, 1989; 8:545-58.

40. Skoutakis VA, Carter CA, Mickle TR, Smith VH, Arkin CR, Alissandratos J. Review of diclofenac and evaluation of its place in therapy as a non-steroidal anti-inflammatory agent. Drug Intelligence and Clinical Pharmacy. 1988; 22:850-9.

41. Friman $C$, Johnston $C$, Chew $C$ and Davis P. Effect of diclofenac sodium, tolfenamic acid and indomethacin on the production of superoxide induced by $\mathrm{N}$-formyl-methionyl-leucylphenylalanine in normal human polymorphonuclear leukocytes. Scandinavian Journal of Rheumatology. 1986; 15:41-6.

42. Al-Tuwaijri AS and Mustafa AA. Verapamil enhances the inhibitory effect of diclofenac on the chemiluminescence of human polymorphonuclear leukocytes and carrageenan-induced rat's paw oedema, International Journal of Immunopharmacology. 1992; 14:83-91.

43. Claus EP and Tyler V."Pharmacognosy" $5^{\text {th }}$ ed., Lea and Febiger, Philadelphia. 1967:271-273.

44. Geissman TA. The Chemistry of Flavonoids. The MacMillan Company, New York. 1962:318-320.

45. Peach K and Tracey MV. Moderne Methoden Der PflanzenAnalyse, Springer - Verlag, Berlin, 1955:3:450.
46. Cottiglia F, Casu L, Bonsignore L, Casu M. Floris C, Sosa S, Altinier $\mathrm{G}$ and Della Logia R. Topical anti-inflammatory activity of flavonoids and a new xanthone from Santolina insularis. Zeitschrift f'ur Naturforschung. 2005; 60:63-66.

47. Just MJ, Recio MC, Giner RM, Cuellar MJ, Manez S, Bilia AR and Rios JL. Anti-inflammatory activity of unusual lupine saponins from Bupleurum fruticescens. Planta Med 1998; 64:404-407.

48. Navarro P, Giner RM, Recio MC, Manez S, Cerda-Nicolas M and Ríos JL. In vivo anti-inflammatory activity of saponins from Bupleurum rotundifolium. Life Sci 2001; 68:1199-1206.

49. Maxwell SJ. Prospects for the use of antioxidant therapies. Drugs. 1995; 49:345-352.

50. Sato M, Ramarathnam N, Suzuki Y, Ohkubo T, Takeuchi M and Ochi H. Varietal differences in the phenolic content and superoxide radical scavenging potential of wines from different sources. J. Agri. Food Chem. 1996; 44:37-41.

51. Rice-Evans C. Wake up to flavonoids. 2000, The Royal Society of Medicine Press Limited, London.

52. Bartosz G. Druga twarz tlenu (The second face of oxygen). 1995, Wydawnictwo Naukowe PWN, Warzszawa (in Polish).

53. Bhandari MR and Kawabata J. Organic acid, phenolic content and antioxidant activity of wild yam (Dioscorea spp.) tubers of Nepal. Food Chem. 2004, 88, 163-169.

54. Rice-Evans CA, Miller NJ and Paganga G. Structure antioxidant activity relationship of flavonoids and phenolic acids. Free Radi. Biol. Med. 1996; 20:933-956.

55. Sartor L, Pexxato E, Dell'Aica I, Caniato R, Biggin S, and Garbisa S. Inhibition of matrix-proteases by polyphenols: chemical insights for anti-inflammatroy and anti-invasion drug design. Biochem. Pharmacol. 2002; 64:229-237.

56. Piskula, M.K. Soy isoflavone conjugation differs in fed and fooddeprived rats. J. Nutr., 2000; 130:1766-1771.

57. Miller DD. 1996. Mineral. In "Food Chemistry" Fennema O.R. (Ed.), p. 618. Marcel Deckker, New York.

58. Yamaguchi F, Ariga T, Yoshimira Y. and Nakazawa H. Antioxidant and anti-glycation of carcinol from Garcinia indica Fruit Rind. J. Agr. Food Chem. 2000; 49:180-186.

59. Baumann J, Wurn G. and Bruchlausen FV. Prostaglandin synthase inhibiting $\mathrm{O}_{2}^{-}$radical scavenging properties of some flavonoids and related phenolic compounds. N-Ss Arch. Pharmacol. 1979; 308: R27-R39.

60. Cao G, Sofic E. and Prior RL. Antioxidant and prooxidant behaviour of flavonoids: structure-activity relationships. Free Rad. Biol. Med. 1997; 22:749-760.

61. Sakanaka S, Tachibana Y. and Okada Y. Preparation and antioxidant properties of extracts of Japanese persimmon leaf tea (kakinoha-cha). Food Chem. 2005; 89:569-574.

62. Rice-Evans CA., Miller NJ. and Paganga G. Antioxidant properties of phenolic compounds. Trend. Plant Science. 1997; 4:152-159. 